\title{
MY FATHER'S HOUSE
}

In my father's house... a plate full of chicken bones, and a wide eyed arch opening the hallway.

I remember before the house caved incushions of gingerbread

and a bicycle with a wet spine

lurching in the rain.

Two brothers pushed its brittle frame through the back door.

The whining of those silvery bones

and the coughing of chains

were as hoarse as the moon's.

The summer of the hurricane

the house fell.

It was a storm of voices,

the winds from my father's belly

then slow rains

watering his chin.

It was the crying of my father

over the chicken plates,

or maybe over the broken back step

or the bare peach tree.

The summer the house fell

its walls lay down,

breathing like tired men.

The curtains whispered,

then folded their flowery ears.

The china splashed.

It was a storm of glass,

of broken colors.

The eyes of my father were splintered

and bled with crystal. 
Only the cat could seeloosening its fingers on a wide, backyard birch with the gold spoons of its eyes, saying

The house is falling The house is falling

with the gold flash from its eyes warning the tree. 